\title{
Multicentric lymphoma with metastasis in the central nervous system in a dog
}

[Linfoma multicêntrico com metástase no sistema nervoso central em cão]

\author{
K.P. Aptekmann, C.E., Okamoto, K.C.H., Campos, R.K., Takahira* \\ ${ }^{1}$ Universidade Estadual Paulista - Faculdade de Medicina Veterinária e Zootecnia - UNESP \\ Campus de Botucatu - SP \\ Distrito de Rubião Jr. - Caixa Postal 560 \\ 18618-000 - Botucatu, SP
}

\begin{abstract}
Multicentric lymphoma was diagnosed in a two-year-old dog with respiratory distress, dysorexia, abdominal enlargement and generalized lymphadenopathy. Immunohistochemical examination showed Tcell origin with CD3+ e CD79- expression. After five weeks, progressive neurological deficits and neoplastic lymphocytes were identified in the cerebrospinal fluid. Histopathological examination showed neoplastic cell invasion in the spleen, lymph nodes, cerebrum and cerebellum.
\end{abstract}

Keywords: dog, lymphoma, central nervous system

\section{RESUMO}

Linfoma multicêntrico foi diagnosticado em um cão com dois anos de idade que apresentava insuficiência respiratória, aumento de volume abdominal (ascite) e linfoadenopatia generalizada. O exame imunoistoquímico revelou origem de células T com expressão CD3+ e CD79-. Após cinco semanas, o cão apresentou déficits neurológicos progressivos, sendo identificada a presença de linfócitos neoplásicos no líquor. O exame histopatológico demonstrou invasão de células neoplásicas no baço, linfonodos, cérebro e cerebelo.

Palavras-chave: cão, linfoma, sistema nervoso central

\section{INTRODUCTION}

Lymphoma or lymphosarcoma is one of the most common neoplasms of the hematopoietic system, and account for approximately $7 \%$ to $24 \%$ off all canine neoplasia. (Vail et al., 2001; Rallis et al., 1992). The classification can be made on the basis of anatomic location and histological criteria. The most common anatomic forms of lymphoma include the multicentric, cranial mediastinal, gastrointestinal, and cutaneous. Primary extranodal forms such as those occurring in the central nervous system (CNS), eyes, bone, testes, and nasal cavity are less commonly observed (Vail et al., 2001; Sequeira et al., 1999). This paper describes a multicentric lymphoma with metastasis in the CNS.

\section{CASE REPORT}

A two-year-old, female Labrador retriever was presented with a history of lethargy, respiratory distress, dysorexia, abdominal enlargement with 20 days of evolution. Physical examination revealed generalized lymphadenopathy, mucous

Recebido para publicação em 1 de novembro de 2003

Recebido para publicação, após modificações, em 15 de junho de 2004

*Autor para correspondência (corresponding author)

E-mail: takahira@fmvz.unesp.br 
membrane pallor, hepatomegaly and splenomegaly and muffled heart and lung sounds.

Hematological examination showed normocytic normochromic anemia and leukocyte and platelet counts within the reference range (Jain, 1993). Serum biochemical analysis showed elevated serum alanine aminotransferase (ALT), alkaline phosphatase (ALP) and $\gamma$-glutamyl transferase (GGT) activities and a decrease in total serum protein and albumin. Urinalysis and creatinine, urea and calcium serum levels were normal. Hepatosplenomegaly, pleural effusion and a cranial mediastinal mass were evident on abdominal and thoracic radiographs, respectively. Lymph node cytology was diagnostic for lymphocytic lymphoma. The immunophenotype of the tumor showed T-cell origin with $\mathrm{CD} 3+$ e CD 79- expression. Immunohistochemistry techniques were developed in Immunohistochemical Laboratory of the Pathology Service in UNESP. It was used the immunoperoxidase techniques, in agreement with Hsu (1981), using lymphoid anti-CD3 marker (Dako A0452), a polyclonal antibody, for T-cells and anti-CD79a (Dako M7051) marker, a monoclonal antibody, and for B-cells (Moura et al., 2001).

Treatment with systemic chemotherapy was initiated in an attempt to induce remission using cyclophosphamide $^{1}$ vincristine $^{2}$ and prednisone ${ }^{3}$ (COP) in doses recommended in the literature (Vail et al., 2001). Besides, nutritional management was established to provide specific oncology nutritional support and to reduce toxicity associated with chemotherapy (Ogilvie, 1998). Diet with low levels of simple carbohydrates and moderate levels of highquality protein, fiber and fat was established.

In the course of five weeks, the dog was healthy, except after chemotherapy administration, when it presented vomiting and anorexia during one or two days. A complete blood count was performed periodically to control drugs side effects, as myelotoxicity. Antibiotics and immunomodulatory drugs were given when necessary.

\footnotetext{
${ }^{1}$ Genuxal ${ }^{\circledR} 50 \mathrm{mg}$, Asta Médica, Brasil

${ }^{2}$ Tecnocris ${ }^{\circledR} 1 \mathrm{mg}$, Zodiac, Brasil

${ }^{3}$ Prednisona ${ }^{\circledR} 20 \mathrm{mg}$, Neo-Química, Brasil
}

After the fifth week, the dog had signs of head tremoring (partial seizure), anorexia, lethargy and vomiting. Results of routine hematological, urinalysis and blood gas analysis showed normal values. The biochemical analysis revealed hypocalemia. Symptomatic and support treatment was accomplished. The dog was treated with fluid therapy (Ringer's solution) added with $\mathrm{KCl}$ 19.1\%. Metoclopramide and ranitidine were administered for vomiting control and ampicilin for prevention of systemic infections.

Despite the treatment, the clinical signs of the dog continued to get worse. After two days, neurological examination showed progressive neurological deficits, hyperesthesia, ataxia followed by tetraplegic, intention tremors, behavioral changes (depression), hyperreflexia and horizontal nistagmus with the last phase to the right. Cranial nerve examination was abnormal with hyposmia, menace reaction and facial reflex decreased. An ophthalmic examination was performed and did not reveal any abnormalities.

Cerebrospinal fluid (CSF) was collected from the cerebellomedullary cistern. CSF analysis revealed elevated nucleated cell count and protein concentration. Cytological examination revealed a population of lymphoid cells with marked anisocytosis and anisokaryosis, evident nucleoli, basophilic cytoplasm and atypical mitotic figures (Fig. 1).

The previous chemotherapy was suspended and a lomustine $^{1}$ (CCNU) protocol was established in agreement with the literature (Fan and Kitchell, 2000). Because of the rapid course of the disease, the poor prognosis and worsening of the clinics signs, the animal was sacrificed after two days of the CCNU protocol, with agreement of the owner.

At necropsy, no macroscopic lesions in CNS were observed, except for the cerebral congestion. Histological examination revealed neoplastic lymphoid cell infiltration of the spleen, all lymph nodes, cerebellum and cerebrum (Fig. 2).

\footnotetext{
${ }^{1}$ Citostal $^{\circledR} 40 \mathrm{mg}$, Bristol-Myers Squibb, Brasil
} 


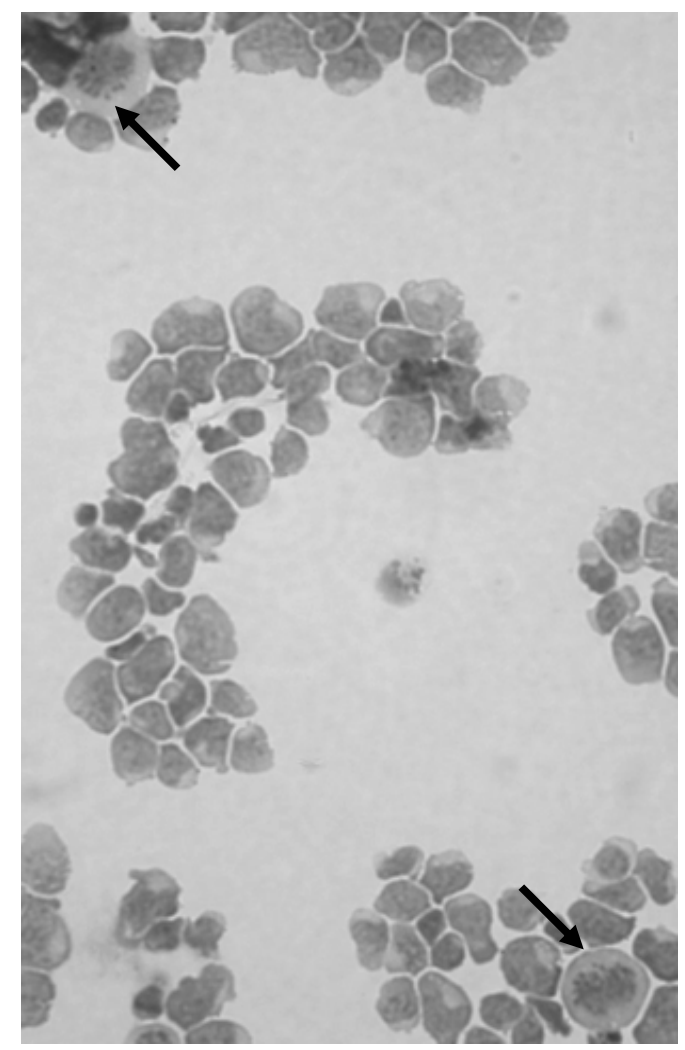

Figure 1. Cerebrospinal fluid with lymphoid cells. Note the presence of anisocytosis and anisokaryosis, evident nucleoli, basophilic cytoplasm and atypical mitotic figures (arrows) (May-Grünwald Giemsa, 1000×).

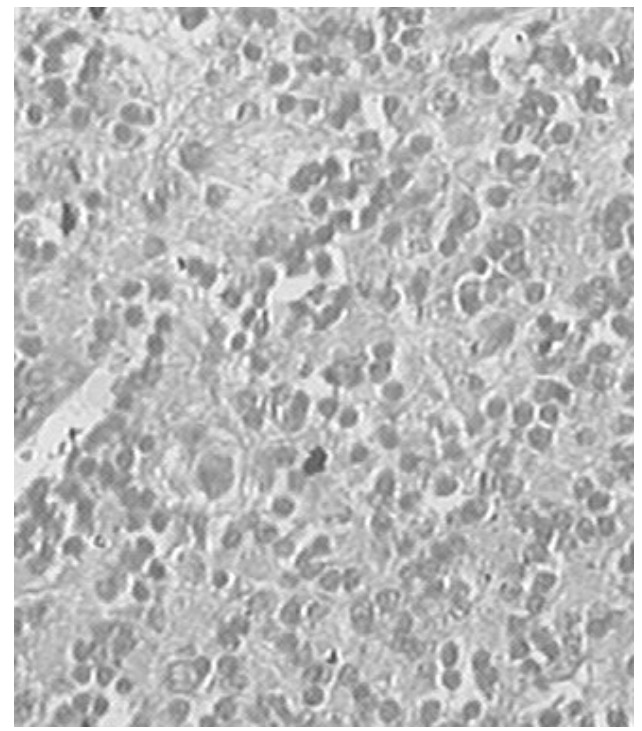

Figure 2. Neoplastic cells infiltrate in cerebellum granular layer (HE, 400x).

\section{DISCUSSION AND CONCLUSION}

Lymphoma within the CNS develops most commonly as part of a multicentric or systemic process (Long et al., 2001), as observed in this report. The clinical signs produced by $\mathrm{CNS}$ tumors are nonspecific and depend on the location of the lesion (Fondevila et al., 1998). Animals can present seizures, cranial nerve deficits, paresis, behavioral changes and progressive ataxia (Rosin, 1982; Couto et al., 1984; Long et al., 2001; Fighera et al., 2002). This dog had neurological signs compatible with multifocal alterations that were confirmed by the histological exam.

The characteristics of the CSF in dogs with CNS lymphoma include high white blood cell counts and protein, and $95 \%$ to $100 \%$ of abnormal lymphoid cells (Couto et al., 1984), as described in this case. Histological or cytological examination is probably the most definitive way to diagnose lymphoma in CNS (Rosin, 1982); however, histological examination usually is limited to the necropsy. There are other techniques to diagnose CNS tumors, as computerized tomography and magnetic resonance imaging (Fulton and Steinberg, 1990; Kent et al., 2001), nevertheless these are not easily available in Brazil, yet.

Identification of the immunophenotype is important in the prognostic and has become an essential step in their classification because of the relationship between biological behavior and response to therapy. T-cell lymphoma has a worse prognosis than B-cell lymphomas. Antibody markers to CD3 and CD79a show cross-reactivity across species lines of B cells and T cells respectively (Milner et al., 1996; Teske et al., 1994; Fournel-Fleury et al., 2002).

A wide variety of chemotherapeutic protocols for the management of canine lymphoma, using single agents or combinations of drugs, have been effective in inducing remission. However, there is no consensus regarding the optimal treatment in terms of efficacy, patient survival and toxicity (Rosenthal, 1990; Rosenthal and MacEwen, 1990; Dobson and Gorman, 1994). In veterinary patients with multicentric lymphoma, it can be used a relatively simple and low-cost protocol, as COP for example (Dobson and Gorman, 1994; Vail et al., 2001). This is well 
tolerated by the animals and results in a $60 \%$ to $70 \%$ complete response rate with a median survival of six to seven months (Cotter and Goldstein, 1983). The dog presented a good response until the fifth week of therapy when it started to show neurological signs. Lomustine was introduced because of its high lipid solubility and ability to cross the blood-brain barrier (Fulton and Steinberg, 1990; Pfaff et al., 2000; Fan and Kitchell, 2000; Fan et al., 2002). Despite of the change in protocol, the lymphoma was in advanced stage and the dog did not respond to the therapy.

This report is important due to an uncommon clinical presentation of a multicentric lymphoma. In spite of the good response to chemotherapy, it is essential to follow the clinical signs and laboratorial exams in patients with lymphoma to search metastasis. Besides, it is essential to make CSF analysis and immunophenotype for diagnosis and prognosis of CNS neoplasm.

\section{REFERENCES}

COTTER, S.M.; GOLDSTEIN, M.A. Treatment of lymphoma and leukemia with cyclophosphamide, vincristine, and prednisone. J. Am. Anim. Hosp. Assoc., v.19, p.159-165, 1983.

COUTO, C.G.; CUllen, J.; PEDROIA, V. et al. Central nervous system lymphosarcoma in the dog. J. Am. Vet. Med. Assoc., v.184, p.809-813, 1984.

DOBSON, J.M.; GORMAN, N.T. Canine multicentric lymphoma 2: comparison of response to two chemotherapeutic protocols. $J$. Small Anim. Pract., v.35, p.9-15, 1994.

FAN, T.M.; KITCHELL, B.E. Lomustine. Compend. Contin. Educ. Pract. Vet., v.22, p.934936, 2000.

FAN, T.M.; KITCHELL, B.E.; DHALIWAL, R.S. et al. Hematological toxicity and therapeutic efficacy of lomustine in 20 tumor-bearing cats: critical assessment of a practical dosing regimen. J. Am. Anim. Hosp. Assoc., v.38, p.357-363, 2002.

FIGHERA, R.A.; SOUZA, T.M.; BARROS, C.S.L. Linfossarcoma em cães. Ciênc. Rural, v.32, p.895-899, 2002.
FONDEVILA, D.; VILAFRANCA, M.; PUMAROLA, M. Primary central nervous system T-cell lymphoma in a cat. Vet. Pathol., v.35, p.550-553, 1998.

FOURNEL-FLEURY, C.; PONCE, F.; FELMAN, P. et al. Canine T-cell lymphomas: a morphological, immunological, and clinical study of 46 new cases. Vet. Pathol., v.39, p.92109, 2002.

FULTON, L.M.; STEINBERG, H.S. Preliminary study of lomustine in the treatment of intracranial masses in dogs following localization by imaging techniques. Vet. Med. Surg.: Small Anim., v.5, p.241-245, 1990.

HSU, S.; RAINE, L.; FANGER, H. Use of avidin-biotin peroxidase complex (ABC) in immunoperoxidase techniques: a comparison between $\mathrm{ABC}$ and unlabeled antibody (PAP) procedures. J. Histochem. Cytochem., v.29, p.577-580, 1981.

JAIN, N.C. Essentials of veterinary hematology. Philadelphia: Lea \& Febiger, 1993. 417p.

KENT, M.; LAHUNTA, A.; TIDWELL, A.S. MR imaging findings in a dog with intravascular lymphoma in the brain. Vet. Radiol. Ultrasound, v.42, p.504-510, 2001.

LONG, S.N.; JOHNSTON, P.E.J.; ANDERSON, T.J. Primary T-cell lymphoma of the central nervous system in a dog. J. Am. Vet. Med. Assoc., v.218, p.719-722, 2001.

MILNER, R.J.; PEARSON, J.; NESBIT, J.W. et al. Immunophenotypic classification of canine malignant lymphoma on formalin-fixed paraffin wax-embedded tissue by means of CD3 and CD79a cell markers. J. Vet. Res., v.19, p.309313, 1996.

MOURA, V.M.B.D.; SEQUEIRA, J.L.; AMORIM, R.L. et al. Immunophenotyping of canine limphoma in paraffin embedded tissue. Rev. Educ. Cont. CRMV - SP., v.4, p.71-75, 2001.

OGILVIE, G.K. Interventional nutrition for the cancer patient. Clin. Tech. Small Anim. Pract., v.13, p.224-231, 1998.

PFAFF, A.D.; MARCH, P.A.; FISHMAN, C. Acute bilateral trigeminal neuropathy associated with nervous system lymphosarcoma in a dog. $J$. Am. Anim. Hosp. Assoc., v.36, p.57-61, 2000. 
RALLIS, T.; KOUTINAS, A.; LEKKAS, S. et al. Lymphoma (malignant lymphoma, lymphosarcoma) in the dog. J. Small Anim. Pract., v.33, p.590-596, 1992.

ROSENTHAL, R.C. The treatment of multicentric canine lymphoma. Vet. Clin. North Am.: Small Anim. Pract., v.20, p.1093-1105, 1990.

ROSENTHAL, R.C.; MacEWEN, E.G. Treatment of lymphoma in dogs. J. Am. Vet. Med. Assoc., v.196, p.774-781, 1990.

ROSIN, A. Neurologic disease associated with lymphosarcoma in ten dogs., J. Am. Vet. Med. Assoc., v.181, p.50-53, 1982.
SEQUEIRA, J.L.; FRANCO, M.; BANDARRA, E.P. et al. Características anatomoclínicas dos linfomas caninos na região de Botucatu, São Paulo. Arq. Bras. Med. Vet. Zootec., v.51, p.245249, 1999.

TESKE, E.; HEERDE, P.V.; RUTTEMAN, G.R. et al. Prognostic factors for treatment of malignant lymphoma in dogs. J. Am. Vet. Med. Assoc., v.205, p.1722-1728, 1994.

VAIL, D.M.; MacEWEN, E.G.; YOUNG, K.M. Canine lymphoma and lymphoid leukemias. In: WITHROW, S.J.; MacEWEN, E.G. (Eds.). Small animal clinical oncology. Philadelphia: W.B. Saunders, 2001. p.559-591. 